\title{
Cranial and skeletal growth patterns in red foxes (Vulpes vulpes L., 1758)
}

\section{Jan Englund}

\begin{abstract}
Different year-classes of red foxes (Vulpes vulpes) grow to the same mean size during their first autumn of life in areas with a good food supply. Most parts of the cranium, mandible and long bones stop growing during the September-November period in yearlings. The zygomatic width is an exception and continues to grow throughout the winter. Several parts of the cranium and mandible continue to increase for many years.
\end{abstract}

KEW WORDS: Vulpes vulpes, skeletal growth, age, food abundance. Jan Englund [je.fox@swipnet.se], Swedish Museum of Natural History, Section of Vertebrate Zoology, S-104 05
Stockholm, Sweden.

\section{Особенности роста черепа и скелета у лисицы (Vulpes vulpes L., 1758)}

\begin{abstract}
Ян Энглунд
РЕЗЮМЕ. Лисицы (Vulpes vulpes) различных возрастных групп достигают в среднем сходных размеров в течение первой осени жизни в районах с хорошей кормовой базой. У сеголеток большинство отделов черепа, нижней челюсти и длинных костей конечностей прекращает расти к сентябрю-ноябрю. Исключение составляет лишь скуловая ширина, которая продолжает увеличиваться в течение зимы. Некоторые отделы черепа и нижней челюсти продолжают увеличиваться в течение многих лет.
\end{abstract}

КЛЮЧЕВЫЕ СЛОВА: Vulpes vulpes, череп, скелет, рост, возраст, обилие пищевых ресурсов.

\section{Introduction}

Huson \& Page (1980) showed that several parts of Welsh red fox (Vulpes vulpes) crania grow in size up to the age of four years. In female foxes, fewer parts increase in size than in males, and the changes are proportionally smaller. Swiss foxes from Berne reach their maximum total skull length by November of the first year. In contrast, the weight of the skull only reaches 80 to $90 \%$ of adult weight by that time, and does not continue to grow during the winter (Lüps, 1974). Slovakian adult male foxes have larger skulls than yearlings. There is, however, no corresponding difference between old and young females (Hell et al., 1989).

According to Lindström (1983) the growth of the mandible stops in November-December for subadult female foxes living in the southern part of the coniferous belt in Sweden. When food is scarce, the vixens will not be fully grown at that time. These foxes presumably in contrast to others he says compensate for this delay by further growth later in life.

The contents of fox stomachs show that the availability of small rodents varied a little between years in the studied area in southern Sweden, but at a high level and to a lesser degree than in northern Sweden. There is also ample alternative food available in the south, and therefore the food supply is relatively stable at a high level year after year (Englund, 1965, 1970, 1980).

The present paper addresses the question of whether or not foxes living under such food conditions continue to grow for several years or not.

\section{Material and methods}

The present paper is based on data from skulls, mandibles and long bones measured on 1800 foxes shot between 1965 and 1971 in the agricultural counties of Uppland, Södermanland, and Östergötland in southern Sweden. These provinces are situated between $58.5^{\circ}$ and $60^{\circ} \mathrm{N}$ latitude.

Although the material was collected during all months of the year, the majority of the specimens were shot between November and March, with less than 100 foxes, including the juveniles, having been shot between May and September.

Because the carcasses were collected from hunters often the long bones were missing or parts of the skeleton were destroyed. This explains the varying sample size among variables (see Tables).

The skeletal parts were simmered for several hours in water with domestic detergent before cleaning. 
Table 1. Age specific means of some cranial measurements in a sample of male foxes from an agricultural area in southern Sweden. Ages are given as years and the week numbers during which the foxes were killed. Means in mm; standard deviations and the number of foxes are given in parentheses.

\begin{tabular}{|c|c|c|c|c|c|c|c|}
\hline Ages & \begin{tabular}{|c|}
$\begin{array}{c}\text { Greatest cranial } \\
\text { length }\end{array}$ \\
\end{tabular} & $\begin{array}{c}\text { Condylobasal } \\
\text { length }\end{array}$ & Palatal length & Braincase width & Mastoid width & $\begin{array}{c}\text { Zygomatic } \\
\text { width }\end{array}$ & P4 length \\
\hline $0.18-0.21$ & $88.3(-/ 1)$ & $78.9(-/ 1)$ & $40.6(-/ 1)$ & $42.6(-/ 1)$ & $37.2(-/ 1)$ & $51.2(-/ 1)$ & - \\
\hline $0.22-0.26$ & $111.2(-/ 1)$ & - & $49.6(-/ 1)$ & - & - & - & - \\
\hline $0.27-0.30$ & $128.5(5.37 / 2)$ & $121.4(7.50 / 2)$ & $60.4(-/ 1)$ & $46.6(1.10 / 3)$ & $45.7(0.88 / 4)$ & - & - \\
\hline $0.31-0.35$ & $144.7(7.47 / 4)$ & $138.0(5.61 / 4)$ & $73.8(1.55 / 3)$ & $48.5(1.69 / 4)$ & $46.9(2.88 / 5)$ & $74.2(1.13 / 2)$ & $14.1(0.49 / 4)$ \\
\hline $0.36-0.39$ & $151.7(4.75 / 10)$ & $145.2(2.98 / 9)$ & $74.8(3.18 / 11)$ & $47.7(1.38 / 17)$ & $48.1(1.34 / 17)$ & $75.6(1.52 / 4)$ & $14.2(0.55 / 22)$ \\
\hline $0.40-0.44$ & $153.5(3.95 / 26)$ & $145.6(3.90 / 25)$ & $76.0(2.54 / 30)$ & $48.7(1.34 / 38)$ & $48.7(1.43 / 40)$ & $77.1(1.77 / 19)$ & $14.3(0.54 / 54)$ \\
\hline $0.45-0.48$ & $153.2(5.27 / 45)$ & $145.8(4.59 / 41)$ & $75.8(2.79 / 49)$ & $48.4(1.23 / 41)$ & $48.4(1.29 / 44)$ & $78.8(2.72 / 21)$ & $14.3(0.61 / 57)$ \\
\hline $0.49-0.53$ & $154.2(5.55 / 46)$ & $146.9(5.13 / 46)$ & $76.3(3.19 / 55)$ & $48.2(1.24 / 43)$ & $48.3(1.46 / 45)$ & $79.0(2.81 / 23)$ & $14.2(0.54 / 57)$ \\
\hline $0.00-0.04$ & $155.8(5.11 / 48)$ & $148.2(4.99 / 41)$ & $76.3(3.00 / 63)$ & $49.0(1.41 / 44)$ & $48.7(1.45 / 48)$ & $80.7(2.74 / 37)$ & $14.5(0.52 / 68)$ \\
\hline $0.05-0.08$ & $154.3(4.30 / 79)$ & $147.0(3.84 / 76)$ & $76.4(2.39 / 93)$ & $48.8(1.09 / 76)$ & $48.7(1.29 / 77)$ & $80.9(2.15 / 63)$ & $14.5(0.58 / 98)$ \\
\hline $0.09-0.13$ & $154.0(4.90 / 109)$ & $146.7(4.42 / 108)$ & $75.8(2.79 / 122)$ & $48.5(1.23 / 105)$ & $48.6(1.55 / 109)$ & $81.0(2.56 / 77)$ & $14.4(0.63 / 127)$ \\
\hline $0.14-1.26$ & $154.4(4.58 / 26)$ & $146.6(4.69 / 24)$ & $76.0(2.69 / 29)$ & $49.0(1.15 / 25)$ & $48.8(1.45 / 24)$ & $81.6(2.77 / 21)$ & $14.3(0.59 / 30)$ \\
\hline $0.49-1.26$ & $154.4(4.87 / 308)$ & $147.0(5.50 / 295)$ & $76.1(2.78 / 362)$ & $48.7(1.24 / 293)$ & $48.6(1.45 / 303)$ & $80.7(2.59 / 221)$ & $14.4(0.59 / 380)$ \\
\hline $1.27-2.26$ & $155.8(5.40 / 168)$ & $148.3(4.77 / 160)$ & $76.9(3.34 / 187)$ & $49.0(1.20 / 156)$ & $49.0(1.57 / 162)$ & $83.1(2.41 / 155)$ & $14.4(0.58 / 189)$ \\
\hline $2.27-3.26$ & $155.9(4.77 / 92)$ & $148.4(4.45 / 89)$ & $76.9(2.67 / 106)$ & $49.1(1.39 / 92)$ & $49.0(1.47 / 95)$ & $83.7(2.47 / 93)$ & $14.5(0.58 / 110)$ \\
\hline $3.27-4.26$ & $158.0(5.44 / 33)$ & $149.6(4.97 / 29)$ & $78.0(2.99 / 37)$ & $49.3(1.26 / 36)$ & $49.1(1.21 / 36)$ & $83.8(2.14 / 33)$ & $14.4(0.58 / 42)$ \\
\hline $4.27-5.26$ & $157.9(4.77 / 26)$ & $150.0(4.60 / 25)$ & $77.7(2.87 / 29)$ & $49.4(1.13 / 27)$ & $49.4(1.51 / 29)$ & $85.2(2.42 / 26)$ & $14.4(0.63 / 33)$ \\
\hline $5.27-6.26$ & $160.9(4.81 / 7)$ & $153.2(4.31 / 7)$ & $79.5(3.08 / 8)$ & $49.9(1.18 / 11)$ & $49.8(1.32 / 11)$ & $85.4(2.98 / 11)$ & $14.4(0.50 / 13)$ \\
\hline $6.27-$ & $158.9(5.12 / 12)$ & $151.8(5.27 / 10)$ & $79.9(2.45 / 14)$ & $49.7(1.43 / 17)$ & $49.4(1.71 / 18)$ & $86.7(2.99 / 15)$ & $14.4(0.70 / 18)$ \\
\hline Change/year & 0.9 & 0.8 & 0.5 & 0.2 & 0.2 & 1.0 & - \\
\hline p-value & $<0.001$ & $<0.001$ & $<0.001$ & $<0.001$ & $<0.001$ & $<0.001$ & $>0.492$ \\
\hline Correlation & 0.24 & 0.23 & 0.24 & 0.22 & 0.18 & 0.51 & - \\
\hline SE & 5.0 & 4.6 & 2.9 & 1.2 & 1.5 & 2.6 & - \\
\hline
\end{tabular}

Juveniles were distinguished from older foxes when possible by open sutures in the tibia or by the presence of an open suture between the basioccipital and basisphenoid bones in the cranium (Churcher, 1960). Other foxes were aged by the incremental annuli in the tooth cementum of the canines. The technique used was that described by Jensen \& Nielsen (1968) and modified by Englund (1970).

Cranial measurements taken are as follow (the codes in parentheses correspond to those given in von den Driesch, 1976): greatest length (akrokranion-prosthion) (1); condylobasal length (2); palatal length (the median point of intersection of the line joining the deepest indentations of the choanae to the prosthion) (13a); greatest width of the braincase (29); mastoid width (23); zygomatic width (30); and length of the right upper P4 (L).

Mandibular measurements are: total length (from infradentale to the midpoint of the condyle) (1); distance between the alveoli of the canine $\mathrm{c} 1$ and the $\mathrm{p} 1$; length of $\mathrm{p} 1-\mathrm{p} 4$ (11), and of $\mathrm{m} 1-\mathrm{m} 3$ (10) both measured along the alveoli; thickness of the mandible below the middle of the $\mathrm{m} 1$; and length of the crown of $\mathrm{m} 1$ (13).

Greatest length (GL) was measured on the humerus, the ulna, the radius, and the tibia. Femural length (GLC) was measured from the superior surface of the femoral head to the most distal point of the bone, which for foxes is the greatest length in the femur.

Measurements were recorded to the nearest $0.1 \mathrm{~mm}$ using calipers connected to a computer (Billfors \& Jacobsen, 1974).

Age-specific means and standard deviations for the different variables, as well as the number of foxes measured, are given in Tables $1-6$. The ages are given in years followed by the week during which the animals were killed.

The relationship between skull, mandibular, and long bone sizes and age was analyzed quantitatively for each sex by regression analysis using SPSS/PC + . In all tests yearlings killed earlier than December were excluded. 
Table 2. Age specific means of some cranial measurements in a sample of female foxes from an agricultural area in southern Sweden. Ages are given as years and the week numbers during which the foxes were killed. Means in mm; standard deviations and the number of foxes are given in parentheses.

\begin{tabular}{|c|c|c|c|c|c|c|c|}
\hline Ages & \begin{tabular}{|c|}
$\begin{array}{c}\text { Greatest cranial } \\
\text { length }\end{array}$ \\
\end{tabular} & $\begin{array}{c}\text { Condylobasal } \\
\text { length }\end{array}$ & Palatal length & Braincase width & Mastoid width & $\begin{array}{l}\text { Zygomatic } \\
\text { width }\end{array}$ & P4 length \\
\hline $0.18-0.21$ & - & - & - & - & - & - & - \\
\hline $0.22-0.26$ & - & - & $48.7(1.77 / 2)$ & $44.7(-/ 1)$ & $42.7(-/ 1)$ & - & - \\
\hline $0.27-0.30$ & $114.3(-/ 1)$ & - & $56.1(-/ 1)$ & $46.7(1.91 / 2)$ & $45.7(2.61 / 2)$ & - & - \\
\hline $0.31-0.35$ & $130.2(-/ 1)$ & $125.4(-/ 1)$ & $65.8(-/ 1)$ & $46.4(0.21 / 2)$ & $46.5(1.56 / 3)$ & - & $13.5(0.47 / 5)$ \\
\hline $0.36-0.39$ & $146.7(5.80 / 6)$ & $139.1(5.53 / 6)$ & $71.9(3.67 / 7)$ & $48.3(0.74 / 8)$ & $47.1(0.50 / 8)$ & $76.0(-/ 1)$ & $13.8(0.51 / 12)$ \\
\hline $0.40-0.44$ & $146.2(4.72 / 10)$ & $139.1(4.64 / 10)$ & $72.4(2.69 / 11)$ & $48.1(1.57 / 12)$ & $46.8(1.71 / 14)$ & $73.8(2.82 / 6)$ & $14.1(0.70 / 18)$ \\
\hline $0.45-0.48$ & $146.9(3.95 / 19)$ & $139.2(3.87 / 18)$ & $72.4(2.63 / 21)$ & $47.9(1.21 / 20)$ & $46.4(1.43 / 21)$ & $75.6(1.64 / 15)$ & $13.5(0.58 / 23)$ \\
\hline $0.49-0.53$ & $146.0(4.02 / 16)$ & $139.6(3.42 / 16)$ & $72.1(1.77 / 20)$ & $47.6(1.20 / 11)$ & $46.8(1.70 / 14)$ & $75.0(1.92 / 7)$ & $13.7(0.59 / 22)$ \\
\hline $0.00-0.04$ & $146.2(4.15 / 37)$ & $139.7(3.47 / 31)$ & $72.1(2.20 / 48)$ & $47.7(1.07 / 37)$ & $47.0(1.47 / 36)$ & $75.7(2.45 / 34)$ & $13.8(0.62 / 52)$ \\
\hline $0.05-0.08$ & $146.9(5.08 / 79)$ & $140.2(4.54 / 77)$ & $73.0(2.90 / 98)$ & $47.7(1.12 / 79)$ & $46.9(1.32 / 84)$ & $76.4(2.30 / 67)$ & $13.7(0.58 / 101)$ \\
\hline $0.09-0.13$ & $146.2(4.55 / 107)$ & $139.4(4.27 / 95)$ & $72.7(2.71 / 128)$ & $47.6(1.27 / 95)$ & $46.8(1.33 / 97)$ & $76.5(2.36 / 79)$ & $13.7(0.53 / 131)$ \\
\hline $0.14-1.26$ & $147.4(5.49 / 26)$ & $141.3(5.02 / 23)$ & $73.0(2.72 / 28)$ & $48.0(1.24 / 25)$ & $47.2(1.79 / 26)$ & $77.5(2.50 / 23)$ & $13.7(0.53 / 30)$ \\
\hline $0.49-1.26$ & $146.5(4.72 / 265)$ & $139.9(4.30 / 242)$ & $72.7(2.66 / 322)$ & $47.7(1.18 / 247)$ & $46.9(1.41 / 257)$ & $76.4(2.39 / 210)$ & $13.7(0.56 / 336)$ \\
\hline $1.27-2.26$ & $147.7(4.31 / 143)$ & $141.0(3.91 / 139)$ & $73.3(2.38 / 168)$ & $47.7(1.24 / 139)$ & $47.1(1.26 / 143)$ & $78.2(2.15 / 139)$ & $13.8(0.58 / 176)$ \\
\hline $2.27-3.26$ & $148.4(4.15 / 83)$ & $141.9(3.79 / 80)$ & $73.7(2.32 / 91)$ & $48.0(1.17 / 79)$ & $47.3(1.44 / 81)$ & $78.6(1.74 / 75)$ & $13.8(0.53 / 92)$ \\
\hline $3.27-4.26$ & $147.5(4.31 / 51)$ & $140.9(4.39 / 47)$ & $73.2(2.77 / 61)$ & $48.0(1.33 / 51)$ & $47.1(1.34 / 54)$ & $79.3(2.42 / 48)$ & $13.7(0.52 / 65)$ \\
\hline $4.27-5.26$ & $150.4(4.33 / 28)$ & $142.9(3.92 / 26)$ & $74.0(2.25 / 31)$ & $48.2(1.05 / 27)$ & $47.4(1.31 / 26)$ & $79.8(2.19 / 27)$ & $14.0(0.67 / 35)$ \\
\hline $5.27-6.26$ & $149.7(3.78 / 20)$ & $143.0(3.21 / 19)$ & $74.7(2.25 / 23)$ & $48.4(0.78 / 21)$ & $47.5(1.09 / 22)$ & $80.1(1.84 / 23)$ & $14.0(0.58 / 26)$ \\
\hline $6.27-$ & $149.6(3.09 / 15)$ & $142.5(2.69 / 14)$ & $73.8(2.38 / 19)$ & $48.0(0.95 / 23)$ & $47.5(0.85 / 23)$ & $79.5(2.33 / 18)$ & $13.7(0.37 / 26)$ \\
\hline Change/year & 0.6 & 0.5 & 0.3 & 0.1 & 0.1 & 0.7 & - \\
\hline$p$-value & $<0.001$ & $<0.001$ & $<0.001$ & $<0.001$ & $<0.002$ & $<0.001$ & $>0.045$ \\
\hline Correlation & 0.21 & 0.21 & 0.17 & 0.14 & 0.13 & 0.44 & - \\
\hline SE & 4.4 & 4.0 & 2.5 & 1.2 & 1.3 & 2.3 & - \\
\hline
\end{tabular}

\section{Results}

The mean length of the skulls and bones examined did not vary significantly in size among foxes born in different years $(p>0.05)$. Foxes born in 1968, when the rodent population was at a low (Englund, 1970), reached approximately the same mean size during their first autumn as foxes born in other years when rodents were more common. Foxes of all year classes therefore were lumped together for further treatment.

Some parts of the crania and mandibles of yearlings stop growing in November (Tables 1-6). Other dimensions such as the length of the palate, the width of the braincase and the mastoid width, the length of toothrows $\mathrm{p} 1-\mathrm{p} 4$ and $\mathrm{m} 1-\mathrm{m} 3$ of the mandible, mandibular thickness, and the length of the long bones stop growing even earlier (Tables 1-6 and Fig. 1). Zygomatic width on the other hand increased in size throughout the entire winter (Tables 1, 2 and Fig. 2).

The mean length of most parts of the skulls and mandibles studied were larger among older foxes of both sexes. This was especially apparent for the zygomatic width and the distance between $\mathrm{c} 1$ and $\mathrm{p} 1$ in the mandibles (Tables 1-4 and Fig. 2). In fact the increase in the distance between $\mathrm{c} 1$ and $\mathrm{p} 1$ corresponds to nearly half of the total increase in the length of the mandible. Whether half the mandibular growth takes place between $\mathrm{c} 1$ and $\mathrm{p} 1$, or if that increase of length is just a result of movements of the teeth, is not known.

The mean of the mandibular distances $\mathrm{m} 1-\mathrm{m} 3$ and probably also p1-p4 are not greater in older foxes $(1.27+)$ compared with young foxes $(0.49-1.26)$.

Among males most distal long bones increased in size with age. Old vixens, on the other hand, did not have longer bones than yearlings (Tables 5, 6).

For most variables little of the total variation in size (3-6\%) is explained by the age (Tables 1-6). However, variation in the zygomatic width is explained by age in 26 and $20 \%$ of males and females respectively, and corresponding figures for the distance between $\mathrm{c} 1$ and p1 in the mandible are 20 and $21 \%$. 
Table 3. Age specific means of some mandibular measurements in a sample of male foxes from an agricultural area in southern Sweden. Ages are given as years and the week numbers during which the foxes were killed. Means in mm; standard deviations and the number of foxes are given in parentheses.

\begin{tabular}{|c|c|c|c|c|c|c|}
\hline Ages & Total length & $\mathrm{c} 1-\mathrm{p} 1$ length & p1-p4 length & $\mathrm{m} 1-\mathrm{m} 3$ length & Thickness & $\mathrm{m} 1$ crown length \\
\hline $0.18-0.21$ & $58.8(5.53 / 4)$ & - & - & - & $4.9(0.88 / 4)$ & - \\
\hline $0.22-0.26$ & - & - & - & - & - & - \\
\hline $0.27-0.30$ & $90.3(3.30 / 5)$ & $3.8(-/ 1)$ & $32.3(1.11 / 3)$ & $21.9(-/ 1)$ & $7.4(1.05 / 5)$ & - \\
\hline $0.31-0.35$ & $102.3(8.42 / 6)$ & $3.9(0.53 / 6)$ & $33.8(1.30 / 5)$ & $27.6(1.00 / 4)$ & $7.8(0.48 / 6)$ & $16.4(0.71 / 6)$ \\
\hline $0.36-0.39$ & $109.9(3.44 / 19)$ & $3.1(0.81 / 20)$ & $34.8(1.57 / 20)$ & $27.9(1.26 / 19)$ & $7.5(0.52 / 20)$ & $16.5(0.63 / 22)$ \\
\hline $0.40-0.44$ & $111.6(3.74 / 36)$ & $3.2(0.90 / 41)$ & $34.7(1.31 / 41)$ & $27.9(0.93 / 39)$ & $7.2(0.55 / 44)$ & $16.6(0.74 / 54)$ \\
\hline $0.45-0.48$ & $112.3(3.67 / 50)$ & $3.2(0.80 / 50)$ & $34.8(1.41 / 51)$ & $28.1(1.17 / 48)$ & $7.1(0.37 / 52)$ & $16.8(0.73 / 58)$ \\
\hline $0.49-0.53$ & $113.5(4.00 / 50)$ & $4.0(1.09 / 49)$ & $34.5(1.65 / 49)$ & $27.5(1.11 / 45)$ & $7.1(0.36 / 49)$ & $16.5(0.73 / 57)$ \\
\hline $0.00-0.04$ & $114.2(4.14 / 55)$ & $3.9(1.02 / 54)$ & $35.0(1.57 / 55)$ & $27.8(0.96 / 54)$ & $7.2(0.50 / 55)$ & $16.8(0.63 / 64)$ \\
\hline $0.05-0.08$ & $113.3(3.19 / 87)$ & $4.2(0.82 / 88)$ & $34.8(1.28 / 89)$ & $27.7(0.86 / 84)$ & $7.3(0.42 / 89)$ & $16.7(0.69 / 95)$ \\
\hline $0.09-0.13$ & $113.3(3.66 / 117)$ & $4.1(0.85 / 118)$ & $34.6(1.47 / 118)$ & $27.6(1.17 / 110)$ & $7.3(0.45 / 117)$ & $16.5(0.69 / 128)$ \\
\hline $0.14-1.26$ & $113.2(3.21 / 24)$ & $4.2(0.89 / 25)$ & $34.6(1.33 / 25)$ & $27.3(0.86 / 21)$ & $7.2(0.42 / 25)$ & $16.6(0.77 / 30)$ \\
\hline $0.49-1.26$ & $113.5(3.65 / 333)$ & $4.0(0.91 / 334)$ & $34.7(1.46 / 336)$ & $27.6(1.03 / 314)$ & $7.2(0.44 / 335)$ & $16.6(0.70 / 374)$ \\
\hline $1.27-2.26$ & $114.8(3.69 / 158)$ & $5.0(1.00 / 158)$ & $34.8(1.44 / 158)$ & $27.4(1.09 / 154)$ & $7.3(0.48 / 163)$ & $16.5(0.70 / 187)$ \\
\hline $2.27-3.26$ & $115.1(3.71 / 86)$ & $5.1(0.85 / 83)$ & $34.8(1.49 / 84)$ & $27.6(1.16 / 85)$ & $7.4(0.48 / 88)$ & $16.7(0.73 / 106)$ \\
\hline $3.27-4.26$ & $116.4(3.64 / 29)$ & $5.8(0.98 / 26)$ & $35.0(1.43 / 26)$ & $27.3(1.12 / 28)$ & $7.6(0.47 / 31)$ & $16.6(0.67 / 40)$ \\
\hline $4.27-5.26$ & $117.3(4.24 / 20)$ & $5.6(1.55 / 15)$ & $35.0(1.90 / 15)$ & $27.5(1.03 / 18)$ & $7.6(0.46 / 21)$ & $16.6(0.63 / 32)$ \\
\hline $5.27-6.26$ & $116.1(3.93 / 5)$ & $5.8(1.74 / 6)$ & $35.4(1.50 / 6)$ & $27.3(0.97 / 7)$ & $7.6(0.33 / 8)$ & $16.7(0.47 / 11)$ \\
\hline $6.27-$ & $119.6(2.99 / 11)$ & $5.7(1.02 / 8)$ & $36.3(1.70 / 8)$ & $27.2(1.10 / 11)$ & $7.7(0.60 / 13)$ & $16.4(0.78 / 15)$ \\
\hline Change/year & 0.9 & 0.4 & 0.1 & - & 0.1 & - \\
\hline$p$-value & $<0.001$ & $<0.001$ & $<0.004$ & $>0.136$ & $<0.001$ & $>0.417$ \\
\hline Correlation & 0.30 & 0.45 & 0.11 & - & 0.26 & - \\
\hline SE & 3.7 & 1.0 & 1.5 & - & 0.5 & - \\
\hline
\end{tabular}

\section{Discussion}

During their first year of life, most parts of the skeleton in yearlings stop growing in November; the zygomatic width is being an exception. However, the mean lengths for many of the variables measured were larger among foxes older than one year. Are these differences caused by growth during the second summer in life or later, or are they a result of biased sampling or of something else?

Could the natural mortality rate for small foxes be higher than for large ones, or are small ones more likely to be shot? In both cases, large specimens would survive longer and be represented more often among older foxes. This would give a false impression of growth after the first year of life.

Had the small foxes disappeared faster from the population than the large ones for any of the reasons mentioned, there should have been a steady increase in size throughout the winter among yearlings. Such an increase was not observed except for the zygomatic width.
Some structures, such as the length of P4 in the upper jaw and $\mathrm{m} 1$ in the mandible cannot grow in size in adult foxes. Furthermore, the correlation coefficient between the condylobasal length and the length of $\mathrm{P} 4$ is 0.33 for adult males, and 0.32 for adult females $(p<0.001$ for both sexes). Thus foxes with larger teeth have longer skulls. Therefore, had small foxes for one reason or another disappeared faster from the population than the large ones, the mean size of the teeth should have been larger among older foxes. No such difference was found (Tables 1,2).

My conclusion therefore is that several parts of the skull, mandible and long bones grow in size for more than the first year, at least for foxes living under good food conditions as foxes are in the area studied. This growth is for nearly all skeleton parts supposed to take place only during the summer-autumn period, perhaps caused by the better food supply during that time.

Being larger and stronger probably increase the chance of advancement in the hierarchy. This is very important in populations with intensive social interac- 
Table 4. Age specific means of some mandibular measurements (mostly lengths) in a sample of female foxes from an agricultural area in southern Sweden. Ages are given as years and the week numbers during which the foxes were killed. Means in $\mathrm{mm}$; standard deviations and the number of foxes are given in parentheses.

\begin{tabular}{|c|c|c|c|c|c|c|}
\hline Ages & Total length & c1-p1 length & p1-p4 length & m1-m3 length & Thickness & $\mathrm{m} 1$ crown length \\
\hline $0.18-0.21$ & $64.9(8.11 / 4)$ & - & - & - & $4.9(0.43 / 4)$ & - \\
\hline $0.22-0.26$ & $72.0(2.37 / 3)$ & - & - & - & $6.5(0.21 / 3)$ & - \\
\hline $0.27-0.30$ & $85.5(5.26 / 5)$ & $2.8(-/ 1)$ & - & - & $6.8(0.89 / 5)$ & - \\
\hline $0.31-0.35$ & $98.9(6.85 / 4)$ & $3.9(1.21 / 5)$ & $32.2(1.99 / 5)$ & $26.5(0.67 / 4)$ & $7.4(0.57 / 6)$ & $15.6(0.22 / 6)$ \\
\hline $0.36-0.39$ & $104.0(5.09 / 11)$ & $3.2(0.82 / 11)$ & $32.8(1.25 / 11)$ & $27.4(0.83 / 11)$ & $7.2(0.50 / 11)$ & $16.0(0.68 / 12)$ \\
\hline $0.40-0.44$ & $105.2(4.90 / 12)$ & $3.0(0.77 / 14)$ & $33.0(1.67 / 14)$ & $27.3(1.08 / 12)$ & $7.1(0.45 / 15)$ & $16.4(0.72 / 18)$ \\
\hline $0.45-0.48$ & $106.2(4.07 / 21)$ & $3.1(1.06 / 21)$ & $32.7(1.17 / 21)$ & $26.8(1.01 / 20)$ & $6.8(0.46 / 21)$ & $15.8(0.59 / 22)$ \\
\hline $0.49-0.53$ & $106.3(2.97 / 21)$ & $3.6(0.57 / 21)$ & $33.1(1.29 / 21)$ & $26.5(0.80 / 20)$ & $6.8(0.41 / 21)$ & $15.9(0.70 / 21)$ \\
\hline $0.00-0.04$ & $107.5(3.03 / 45)$ & $3.7(0.64 / 45)$ & $33.1(1.10 / 45)$ & $26.6(1.13 / 45)$ & $7.0(0.39 / 45)$ & $16.0(0.73 / 50)$ \\
\hline $0.05-0.08$ & $108.3(3.69 / 93)$ & $3.8(0.77 / 95)$ & $33.3(1.46 / 93)$ & $26.8(1.10 / 89)$ & $6.9(0.43 / 96)$ & $16.0(0.69 / 99)$ \\
\hline $0.09-0.13$ & $107.5(3.43 / 120)$ & $3.9(0.71 / 119)$ & $33.2(1.51 / 119)$ & $26.6(0.91 / 116)$ & $7.0(0.48 / 120)$ & $15.9(0.60 / 127)$ \\
\hline $0.14-1.26$ & $108.5(3.68 / 27)$ & $3.8(0.73 / 27)$ & $33.7(1.30 / 27)$ & $26.7(0.97 / 23)$ & $7.0(0.39 / 26)$ & $15.9(0.57 / 30)$ \\
\hline $0.49-1.26$ & $107.7(3.47 / 306)$ & $3.8(0.72 / 307)$ & $33.2(1.41 / 305)$ & $26.7(1.00 / 293)$ & $7.0(0.44 / 308)$ & $15.9(0.65 / 327)$ \\
\hline $1.27-2.26$ & $108.9(2.94 / 150)$ & $4.6(0.81 / 146)$ & $33.4(1.32 / 147)$ & $26.7(0.87 / 147)$ & $7.0(0.47 / 153)$ & $16.0(0.64 / 171)$ \\
\hline $2.27-3.26$ & $109.7(3.38 / 76)$ & $4.9(0.73 / 78)$ & $33.5(1.34 / 79)$ & $26.7(0.94 / 82)$ & $7.1(0.41 / 82)$ & $16.0(0.68 / 91)$ \\
\hline $3.27-4.26$ & $108.5(3.41 / 49)$ & $4.9(0.98 / 47)$ & $33.1(1.27 / 48)$ & $26.5(1.01 / 50)$ & $7.3(0.44 / 52)$ & $15.9(0.69 / 60)$ \\
\hline $4.27-5.26$ & $110.7(3.28 / 26)$ & $4.9(0.97 / 25)$ & $33.9(1.60 / 26)$ & $26.7(1.22 / 23)$ & $7.3(0.55 / 30)$ & $16.2(0.65 / 34)$ \\
\hline $5.27-6.26$ & $110.6(2.13 / 12)$ & $5.2(1.44 / 12)$ & $33.6(1.32 / 13)$ & $26.7(1.27 / 13)$ & $7.4(0.59 / 13)$ & $16.2(0.49 / 23)$ \\
\hline $6.27-$ & $109.6(2.57 / 10)$ & $5.1(0.72 / 12)$ & $33.4(1.55 / 13)$ & $26.5(0.98 / 16)$ & $7.6(0.50 / 21)$ & $15.8(0.61 / 23)$ \\
\hline Change/year & 0.5 & 0.3 & - & - & 0.1 & - \\
\hline $\mathrm{p}$-value & $<0.001$ & $<0.001$ & $>0.082$ & $>0.530$ & $<0.001$ & $>0.561$ \\
\hline Correlation & 0.21 & 0.46 & - & - & 0.32 & - \\
\hline SE & 3.3 & 0.8 & - & - & 0.5 & - \\
\hline
\end{tabular}

tion. Low ranking vixens are less likely to reproduce in these populations, and there will be lower survival value for their genes (Macdonald, 1977).

Such social interaction pressure was probably present in the area studied, as a high proportion of the vixens were unproductive in spite of a good food supply. Among one-year old vixens $40-60 \%$ were unproductive, as were 20-25\% of older ones (Englund, 1970, 1980).

The yearly increase of the zygomatic width in older foxes was larger than for the other variables studied. Furthermore that measurement, which also represents the greatest skull width, in contrast to other skeleton parts increased throughout the whole winter, at least among yearlings (Tables 1,2). The growth of the skull breadth thus seems to be the most important factor for competition with other foxes.

Foxes that feed cubs may grow more slowly, and this should be especially obvious in lactating vixens. This may be the reason for the smaller growth in females shown here and by others (Huson \& Page, 1980; Hell et al., 1989).
ACKNOWLEDGMENTS. I wish to express my appreciation to all hunters who have made this investigation possible by sending me the material. I also want to thank the late Professor N.-G. Gejwall (the Institute of Osteology at the University of Stockholm) for allowing me to use equipment in his Department for the automatic registering of measurements. Finally I would like to thank A. Hanson for helping me with the boring job of measuring all of the fox skeletons, A. Bignert for producing the figures, and D. Johnston for correcting my English.

\section{References}

Billfors Ö. \& Jacobsen O. 1974. Automatic measurement and registration equipment for use with computers // Ossa. Vol.1. P.104.

Churcher Ch.S. 1960. Cranial variation in the North American red fox // Journal of Mammalogy. Vol.41. No.3. P.349-360.

Driesch A. von den. 1976. A guide to the measurement of animal bones from archaeological sites // Peabody Museum Bulletin. Vol.1. P.1-136. 
Table 5. Age specific means of the length of long bones in a sample of male foxes from an agricultural area in southern Sweden. Ages are given as years and the week numbers during which the foxes were killed. Means in mm; standard deviations and the number of foxes are given in parentheses.

\begin{tabular}{|c|c|c|c|c|c|}
\hline Ages & Humerus & Ulna & Radius & Femur & Tibia \\
\hline $0.18-0.21$ & - & - & $53.7(-/ 1)$ & - & - \\
\hline $0.22-0.26$ & - & - & - & - & - \\
\hline $0.27-0.30$ & - & - & - & - & - \\
\hline $0.31-0.35$ & - & $142.7(-/ 1)$ & - & - & - \\
\hline $0.36-0.39$ & - & $148.8(4.28 / 5)$ & - & - & $157.6(-/ 1)$ \\
\hline $0.40-0.44$ & $134.8(4.44 / 9)$ & $149.2(5.96 / 11)$ & $127.3(3.54 / 20)$ & $139.8(7.80 / 3)$ & $156.7(5.03 / 12)$ \\
\hline $0.45-0.48$ & $134.6(3.82 / 27)$ & $149.5(3.77 / 28)$ & $127.0(3.73 / 38)$ & $141.8(3.70 / 26)$ & $155.7(4.97 / 28)$ \\
\hline $0.49-0.53$ & $134.3(4.18 / 32)$ & $148.4(5.24 / 40)$ & $126.1(4.41 / 43)$ & $142.0(4.70 / 24)$ & $154.7(6.18 / 34)$ \\
\hline $0.00-0.04$ & $135.8(5.47 / 37)$ & $149.2(5.95 / 51)$ & $127.1(4.84 / 50)$ & $142.0(5.01 / 21)$ & $155.1(5.72 / 37)$ \\
\hline $0.05-0.08$ & $135.4(4.27 / 63)$ & $148.9(4.82 / 72)$ & $127.0(3.96 / 75)$ & $142.3(5.06 / 46)$ & $154.6(4.95 / 53)$ \\
\hline $0.09-0.13$ & $133.6(5.00 / 66)$ & $148.1(5.06 / 95)$ & $126.3(4.29 / 87)$ & $140.2(5.34 / 42)$ & $154.9(5.50 / 73)$ \\
\hline $0.14-1.26$ & $133.8(4.50 / 19)$ & $148.1(5.07 / 24)$ & $126.1(4.29 / 25)$ & $137.2(5.52 / 8)$ & $151.4(6.60 / 8)$ \\
\hline $0.49-1.26$ & $134.6(4.76 / 217)$ & $148.6(5.18 / 282)$ & $126.6(4.32 / 280)$ & $141.3(5.21 / 141)$ & $154.7(5.56 / 205)$ \\
\hline $1.27-2.26$ & $135.2(4.77 / 110)$ & $149.5(4.90 / 138)$ & $127.2(4.34 / 140)$ & $143.3(5.24 / 53)$ & $155.7(6.11 / 88)$ \\
\hline $2.27-3.26$ & $133.8(4.90 / 66)$ & $149.4(4.82 / 79)$ & $127.0(4.22 / 78)$ & $142.1(5.28 / 33)$ & $154.9(5.62 / 49)$ \\
\hline $3.27-4.26$ & $135.6(5.95 / 17)$ & $149.2(4.74 / 18)$ & $127.0(4.55 / 22)$ & $142.9(7.19 / 9)$ & $156.2(7.09 / 14)$ \\
\hline $4.27-5.26$ & $136.0(4.42 / 20)$ & $151.4(4.30 / 23)$ & $128.8(4.01 / 22)$ & $143.5(5.58 / 11)$ & $157.8(5.33 / 17)$ \\
\hline $5.27-6.26$ & $139.2(2.75 / 6)$ & $152.0(4.50 / 11)$ & $129.9(4.80 / 11)$ & $146.5(4.49 / 5)$ & $159.2(6.41 / 8)$ \\
\hline $6.27-$ & $137.6(6.26 / 11)$ & $151.3(6.72 / 15)$ & $129.2(5.02 / 14)$ & $142.2(6.66 / 8)$ & $159.6(7.52 / 8)$ \\
\hline Change/year & - & 0.5 & 0.4 & - & 0.6 \\
\hline $\mathrm{p}$-value & $>0.028$ & $<0.002$ & $<0.002$ & $>0.085$ & $<0.003$ \\
\hline Correlation & - & 0.13 & 0.14 & - & 0.15 \\
\hline SE & - & 5.0 & 4.3 & - & 5.8 \\
\hline
\end{tabular}

Englund J. 1965. Studies on food ecology of the red fox (Vulpes vulpes) in Sweden // Viltrevy. Vol.3. No.4. P.377485.

Englund J. 1970. Some aspects of reproduction and mortality rates in Swedish foxes (Vulpes vulpes), 1961-63 and 1966-69 // Viltrevy. Vol.8. No.1. P.1-82.

Englund J. 1980. Population dynamics of the red fox (Vulpes vulpes L., 1758) in Sweden // Biogeographica. Vol.18. P.107-121.

Hell P., Paule L., Ševcenko L.S., Danko Š., Panigaj L. \& Vitaz V. 1989. Craniometrical investigation of the red fox (Vulpes vulpes) from the Slovak Carpathians and adjacent lowlands // Folia Zoologica. Vol.38. No.2. P.139-155.

Huson L.W. \& Page R.J.C. 1980. Age related variability in cranial measurements in the red fox (Vulpes vulpes) //
Journal of Zoology. Vol.191. No.3. P.427-429.

Jensen B. \& Nielsen L.B. 1968. Age determination in the red fox (Vulpes vulpes L.) from canine tooth sections // Danish Review of Game Biology. Vol.5. No.6. P.1-15. Lindström E. 1983. Condition and growth of red foxes (Vulpes vulpes) in relation to food supply // Journal of Zoology. Vol.199. P.117-122.

Lüps P. 1974. Wachstumsuntersuchungen an der Schädelbasis des Rotfuches (Vulpes vulpes L.) // Zoologische Jahrbücher, Abteilung für Anatomie und Ontogenie der Tiere. Bd.93. No.3. P.288-298.

Macdonald D.W. 1977. The Behavioural Ecology of the Red Fox, Vulpes vulpes; a Study of Social Organisation and Resource Exploitation. PhD Thesis. Oxford University. SPSS/PC+. Statistical Package for Social Sciences, version 3.0. Chicago. 
Table 6. Age specific means of the length of long bones in a sample of female foxes from an agricultural area in southern Sweden. Ages are given as years and the week numbers during which the foxes were killed. Means in mm; standard deviations and the number of foxes are given in parentheses.

\begin{tabular}{|c|c|c|c|c|c|}
\hline Ages & Humerus & Ulna & Radius & Femur & Tibia \\
\hline $0.18-0.21$ & - & - & - & - & - \\
\hline $0.22-0.26$ & - & - & - & - & - \\
\hline $0.27-0.30$ & - & - & - & - & - \\
\hline $0.31-0.35$ & - & $134.0(-/ 1)$ & - & - & - \\
\hline $0.36-0.39$ & $130.7(0.78 / 2)$ & $141.2(2.87 / 4)$ & $122.0(-/ 1)$ & - & - \\
\hline $0.40-0.44$ & $130.1(5.25 / 5)$ & $140.9(3.74 / 6)$ & $120.0(3.44 / 8)$ & $137.0(3.12 / 3)$ & $150.0(4.15 / 4)$ \\
\hline $0.45-0.48$ & $126.7(4.63 / 17)$ & $138.9(5.43 / 14)$ & $118.5(4.70 / 15)$ & $133.1(4.48 / 14)$ & $146.9(4.01 / 15)$ \\
\hline $0.49-0.53$ & $125.5(3.62 / 17)$ & $138.4(4.78 / 18)$ & $117.8(3.81 / 16)$ & $132.9(4.64 / 8)$ & $144.5(4.50 / 13)$ \\
\hline $0.00-0.04$ & $126.1(2.79 / 22)$ & $140.3(4.43 / 35)$ & $119.2(3.78 / 35)$ & $134.9(4.70 / 12)$ & $147.5(4.85 / 28)$ \\
\hline $0.05-0.08$ & $126.7(5.05 / 48)$ & $140.4(5.50 / 69)$ & $119.6(4.53 / 68)$ & $133.8(5.44 / 33)$ & $146.7(6.21 / 60)$ \\
\hline $0.09-0.13$ & $126.1(4.84 / 66)$ & $139.9(4.94 / 98)$ & $119.2(4.24 / 94)$ & $133.3(6.22 / 35)$ & $145.3(5.88 / 70)$ \\
\hline $0.14-1.26$ & $127.4(5.39 / 18)$ & $140.3(6.50 / 21)$ & $120.2(5.34 / 23)$ & $137.0(7.31 / 5)$ & $147.0(9.63 / 9)$ \\
\hline $0.49-1.26$ & $126.3(4.62 / 171)$ & $140.0(5.16 / 241)$ & $119.3(4.34 / 236)$ & $133.8(5.67 / 93)$ & $146.1(6.00 / 180)$ \\
\hline $1.27-2.26$ & $126.9(4.30 / 97)$ & $140.6(4.63 / 131)$ & $119.7(4.12 / 128)$ & $133.9(4.50 / 42)$ & $146.3(5.13 / 84)$ \\
\hline $2.27-3.26$ & $127.6(4.35 / 59)$ & $141.1(4.50 / 76)$ & $120.1(4.11 / 75)$ & $134.9(4.01 / 32)$ & $147.1(4.89 / 51)$ \\
\hline $3.27-4.26$ & $126.6(4.13 / 40)$ & $139.7(4.46 / 48)$ & $119.6(3.74 / 46)$ & $132.5(4.72 / 29)$ & $144.8(6.50 / 35)$ \\
\hline $4.27-5.26$ & $127.3(4.34 / 18)$ & $141.5(4.97 / 21)$ & $120.1(4.08 / 23)$ & $137.4(6.38 / 11)$ & $148.8(6.37 / 16)$ \\
\hline $5.27-6.26$ & $129.1(3.76 / 16)$ & $142.4(4.00 / 16)$ & $121.5(3.65 / 17)$ & $135.4(3.29 / 13)$ & $146.8(4.92 / 11)$ \\
\hline $6.27-$ & $126.2(3.39 / 14)$ & $139.4(3.63 / 22)$ & $119.1(3.40 / 20)$ & $134.3(3.44 / 11)$ & $146.3(4.98 / 16)$ \\
\hline Change/year & - & - & - & - & - \\
\hline p-value & $>0.131$ & $>0.390$ & $>0.175$ & $>0.261$ & $>0.575$ \\
\hline Correlation & - & - & - & - & - \\
\hline $\mathrm{SE}$ & - & - & - & - & - \\
\hline
\end{tabular}



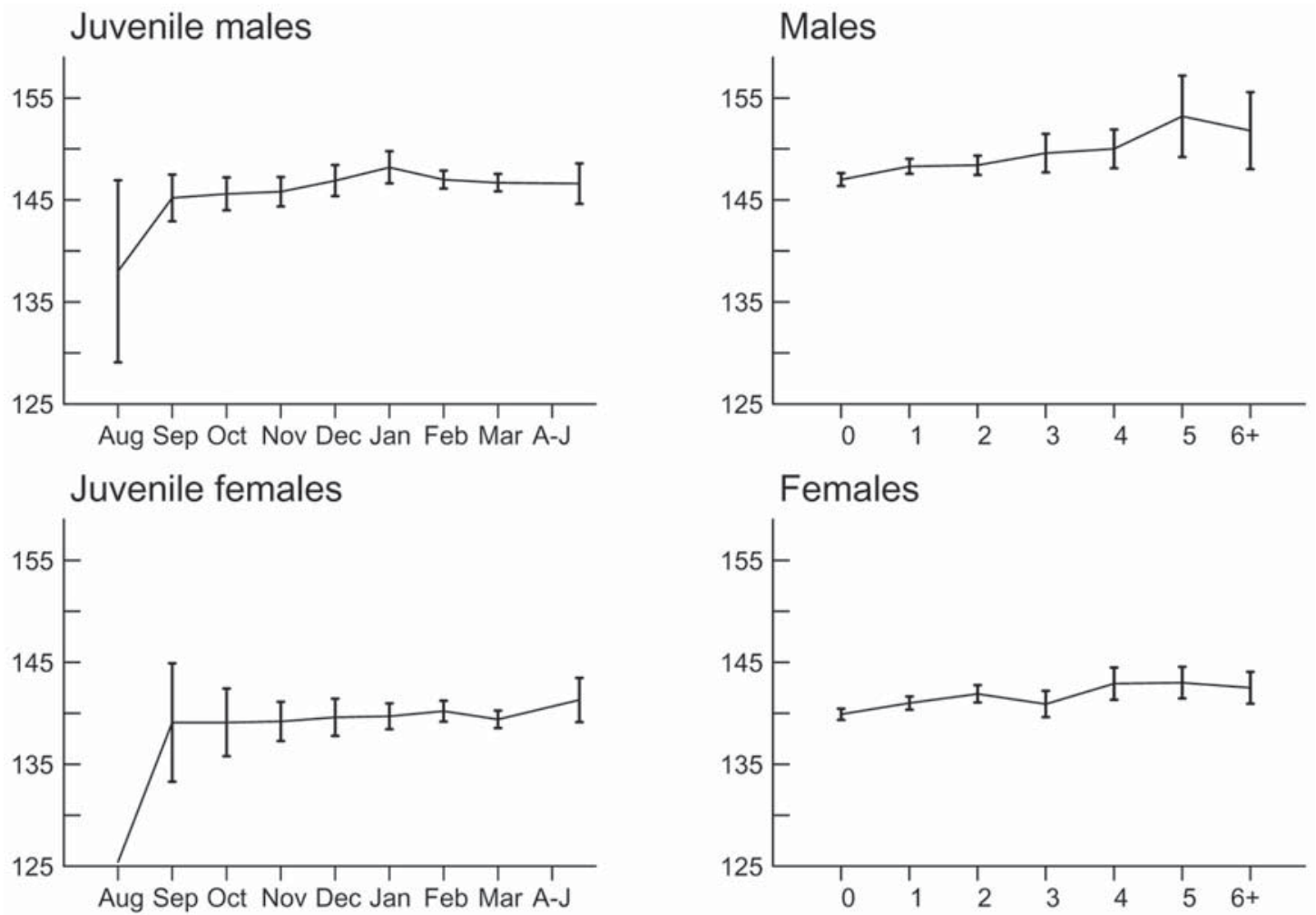

Figure 1. Condylobasal length in $\mathrm{mm}$ (mean $\pm 95 \%$ confidence limits of the mean) in foxes from the counties of Uppland, Södermanland, and Östergötland. Yearlings include foxes killed from December through June of the following year. Older ones up to $6+$ years in age, include foxes killed all year round (July 1 - June 30 ).
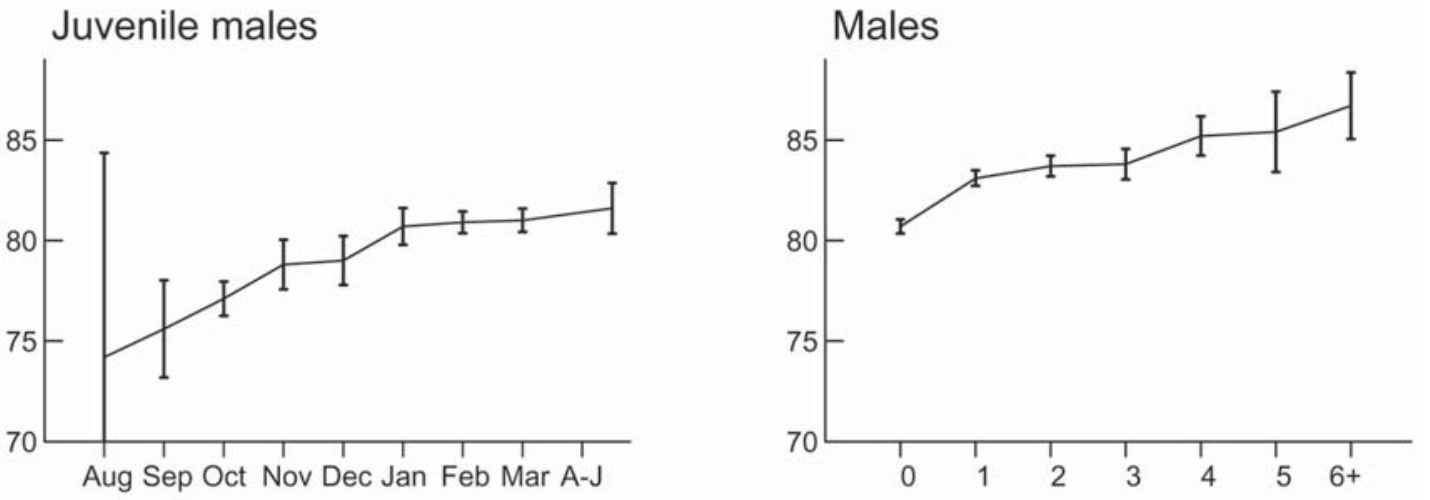

\section{Juvenile females}

\section{Females}
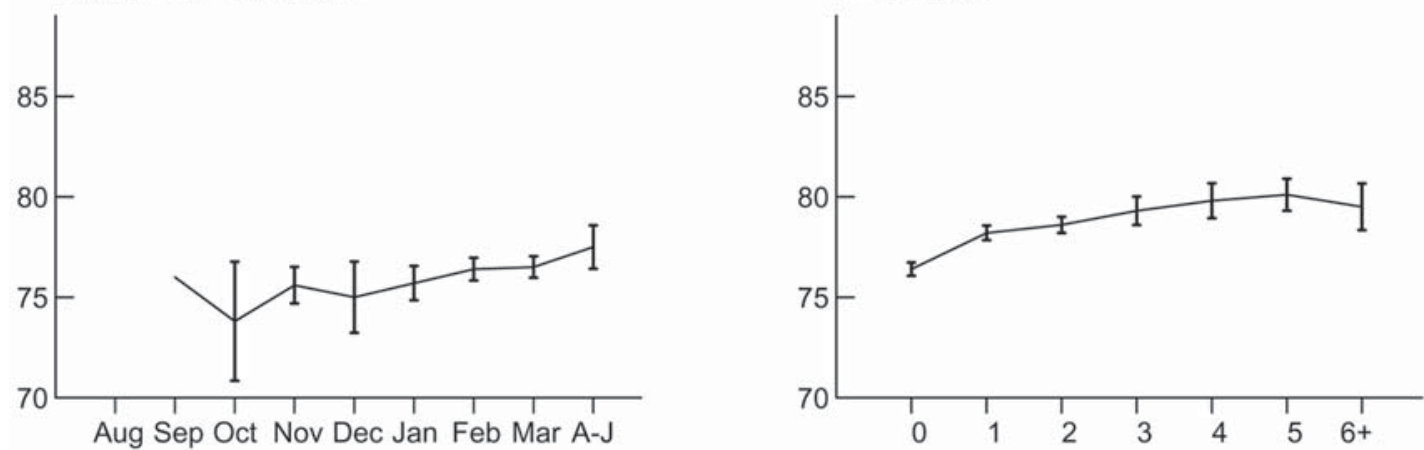

Figure 2. Zygomatic width in $\mathrm{mm}$ (mean $\pm 95 \%$ confidence limits of the mean) in foxes from the counties of Uppland, Södermanland, and Östergötland. Yearlings include foxes killed from December through June of the following year. Older ones up to $6+$ years in age, include foxes killed all year round (July 1 - June 30). 